\title{
Menjadi Modern Tanpa Kehilangan Identitas: Problematika Pelestarian Cagar Budaya di Wilayah Sulawesi Tenggara
}

\author{
Asyhadi Mufsi Batubara \\ Jurusan Arkeologi Universitas Jambi \\ email: didi_roten@yahoo.co.id
}

\begin{abstract}
Abstrak: Modernisasi menjadi hal yang sulit dihindari suatu bangsa yang tergolong sedang berkembang, terlebih Indonesia yang masyarakatnya sangat terbuka. Semangat modernisasi cenderung diterjemahkan dalam bentuk pembangunan infrastruktur yang secara sadar atau tidak telah banyak mengorbankan Cagar Budaya di Indonesia, termasuk di wilayah Sulawesi Tenggara. Ditinjau dari sudut arkeologis, Provinsi Sulawesi Tenggara tergolong sebagai wilayah berkembang dengan budaya material berbentuk cagar budaya dalam jumlah yang banyak dan beragam. Berdasarkan data terakhir pihak Balai Pelestarian Cagar Budaya (BPCB) Makassar, tercatat sebanyak \pm 137 cagar budaya, dimana hanya \pm 14 cagar budaya yang ber-SK. Cagar budaya yang belum di-SK-kan ini tentu rentan terhadap pengaruh-pengaruh negatif modernisme yang cenderung merusak cagar budaya demi beragam kepentingan. Kondisi ini memunculkan tiga pertanyaan penting mengenai kondisi pelestarian cagar budaya di wilayah Sulawesi Tenggara, yakni mengenai persoalan pelestarian, tantangan dan harapan pelestarian, serta pencarian konsep modernisasi infrastruktur yang sejalan dengan pelestarian cagar budaya di Sulawesi Tenggara. Jawaban atas ketiga pertanyaan yang bersifat mendasar tersebut dapat menjadi cerminan dan bahan pemikiran untuk wilayah lain yang juga mengalami persoalan yang hampir sama.
\end{abstract}

Kata kunci: pelestarian, cagar budaya, modernisme, identitas

\begin{abstract}
Modernization becomes mostly inevitable in a developing country, particularly in Indonesia, whose people are very open-minded. The spirit of modernization tends to be translated in the form of infrastructure development, and consciously or not, it has sacrificed Cultural Property (CB) in Indonesia, including in Southeast Sulawesi. From archaeological point of view, Southeast Sulawesi Province is classified as a developing area with the cultural heritage material shaped in large and varied in numbers. Based on the latest data from the Preservative Institution of Cultural Property (Balai Pelestarian Cagar Budaya-BPCB) Makassar, at least 137 cultural heritage (CB) sites are recorded, which only at least $14 \mathrm{CB}$ has been designated as official $\mathrm{CB}$. The cultural heritages that are still not official are certainly susceptible to negative influences of modernism, which tends to damage them for the sake of diverse interests. This condition raises three important questions about the state of preservation of the cultural heritage in Southeast Sulawesi, namely the issue of conservation, the preservation of challenges and expectations, and the search for the modernization concepts of infrastructure in line with the preservation of cultural heritage in Southeast Sulawesi. The answers are the fundamental which could be the reflection and inspiration for other regions that also have similar problems.
\end{abstract}

Keywords: Conservation, Cultural Heritage, Modernism, Identity.

\section{A. Pendahuluan}

Dunia internasional kerap melihat Indonesia sebagai negara kaya budaya dengan tinggalan material yang luar biasa melimpah. Terbukti dari banyaknya ahli dari berbagai negara dengan beragam latar belakang keilmuan menjadikannya sebagai pusat kajian penelitian. Kondisi ini bukanlah barang baru, namun telah berlangsung sejak lama, bahkan sejak Indonesia belum merdeka. Ratusan hasil kajian para peniliti asing tentang budaya dan material culture Indonesia telah dimuat dalam jurnal-jurnal internasional. Keberadaannya tersebar di seluruh wilayah Indonesia, dari Sabang hingga Merauke, dari yang bersifat benda, bangunan, struktur, situs hingga dalam bentuk kawasan. Kekayaan berwujud cagar budaya ini hidup dan mati di tengah-tengah masyarakat yang peduli atau pun sebaliknya. Masyarakat yang memiliki kepedulian memandang cagar budaya sebagai pusaka dan identitas. Sebagian yang lain melihatnya sebatas benda dan bangunan kusam dari masa lalu. Sadar atau tidak, nasib cagar budaya bangsa ini turut ditentukan oleh kedua sudut pandang yang saling berhimpitan di antara lajunya arus modernisasi dan kuatnya pengaruh faktor ekonomi.

Modernisasi menjadi hal yang paling tidak bisa dihindari oleh suatu bangsa yang tergolong sedang berkembang, terlebih seperti Indonesia yang masyarakatnya sangat terbuka pada hal-hal baru. Pengertian modernisasi itu sendiri cukup luas, misalnya Julian Thomas (2004) dalam "Archaeology and 
Modernity" menganggap bahwa modernitas merupakan gambaran peradaban suatu bangsa pada kurun waktu tertentu, terutama dalam cara pandang atau mindset masyarakatnya, serta bagaimana sistem kehidupan sosialnya. Modernisasi secara teori sosial, lebih dimaknai sebagai proses perubahan dari masyarakat tradisional menuju masyarakat modern dengan beberapa ciri yaitu; a). berkembangnya pemikiran rasional, didukungkemampuan dalam bidang teknologi dan pengetahuan umum yang memungkinkannya ada inovasi dan kemajuan ilmu pengetahuan, b). munculnya perdagangan dari kemajuan teknologi, dan pembangunan kota-kota, c). keutamaan individu di atas komunitas, kebebasan individual, tanggung jawab individual serta hak dan kewajibannya, d). peralihan dari masyarakat yang berdasar pada kelompok kekerabatan dan komunitas lokal ke masyarakat yang mendasarkan hubungannya pada keterikatan individual dan kelompok fungsional yang diatur dalam sistem politik, birokrasi, dan kewarganegaraan, e). pengadopsian model-model kultural, sistem pemikiran yang mendunia, f). meningkatnya keterkaitan dengan masyarakat di seluruh dunia baik dalam hal ideologi, pemahaman, solidaritas, sekaligus semakin jelasnya posisi seseorang di dunia (Pelras, 2005: 40).

Semangat modernisasi cenderung diterjemahkan dalam bentuk pembangunan infrastruktur, dan hal semacam ini telah banyak menimpa kota-kota di Indonesia yang semakin dipenuhi bangunan modern beragam rupa. Pembangunan mall, hotel, serta fasilitas pendukung modernitas lainnya semakin marak bermunculan tanpa dilandasi dengan pertimbangan yang baik. Segala hal yang berbau 'lama' dianggap kurang mencerminkan semangat dalam mewujudkan masyarakat modern. Bentuk lama dianggap tidak mewakili era baru dengan segala hal yang baru di dalamnya. Kusno (2009), mengartikan kata 'pembangunan' secara luas menyerupai teori modernisasi yang mencoba memberi identitas baru kepada generasi baru dalam bentuk pengembangan infrastruktur. Sadar atau tidak, pembentukan identitas baru untuk generasi baru melalui bangunan-bangunan modern ini telah banyak mengorbankan bangunan cagar budaya di Indonesia. Sebut saja misalnya penghancuran eks-Kodim Salatiga dan eks-Bioskop Hebedi Pangkal Pinang pada tahun 2010 diganti menjadi pusat perbelanjaan modern (kompas. com. online: 5 Mei 2015). Kasus serupa terus terjadi di berbagai kota, termasuk Yogyakarta yang terkenal sebagai kota pelestari cagar budaya (CB) juga tidak bisa luput dari persoalan modernisasi yang kurang pro-cagar budaya. Tercatat beberapa kasus penghancuran Bangunkan Cagar Budaya (BCB) telah terjadi di Yogyakarta, misalnya kasus bangunan Mardi Wuto sebagai bagian dari Rumah Sakit Mata Dr. Yap, Pasangrahan Ambarukmo, maupun kasus terbaru yang menimpa SMA 17 Yogyakarta.

Proses moderninasi yang kurang pro-cagar budaya ini tidak hanya terjadi di bagian Indonesia Barat saja, namun juga pada kota-kota di wilayah Indonesia Timur, termasuk wilayah Sulawesi Tenggara. Provinsi Sulawesi Tenggara dengan bentuk geografis yang terbagi antara daratan utama dan kepulauan memiliki keanekaragaman etnis dan hasil budaya material dalam jumlah yang banyak dan beragam. Daratan utamanya terbagi dalam beberapa kabupaten/kota yakni; Konawe, Konawe Utara, Konawe Selatan, Kolaka, Kolaka Utara, Bombana, dan Kota Kendari. Adapun wilayah kepulauan secara garis besar dibagi dalam gugus kepulauan Wakatobi (Wanci, Kaledupa, Tomia, Binongko), Buton, Wawonii, dan Muna. Wilayah Sulawesi Tenggara yang begitu luas dihuni beberapa kelompok etnis; Muna, Tolaki, Wolio, Ciacia, Wanci, dan juga etnis pedatang seperti Bugis, Makasar, Jawa dan Bali. Pernyataan ini kemudian diperkuat oleh data hasil penelitian yang dilakukan Balai Pelestarian Cagar Budaya (BPCB) Makasar selaku instansi yang membidangi pelestarian di wilayah Sulawesi Tenggara, Sulawesi Selatan, dan Sulawesi Barat. Beradasarkan data terahir yang dihimpun pihak BPCB Makasar, tercatat sebanyak 137 Cagar Budaya (terdiri dari cagar budaya berbentuk benda, bangunan, struktur, situs, maupun kawasan) yang tersebar diseluruh wilayah Sulawesi Tenggara. Cagar Budaya ini menempati beragam lokasi (di kota, desa, hutan, maupun ladang warga), dengan kondisi fisik yang beragam juga; terawat, tidak terawat, rusak, maupun rata dengan tanah (Laporan Penelitian BPCP Makasar, 2013). Dari jumlah keseluruhan cagar budaya yang ada di Sulawesi Tenggara (137 CB), baru $\pm 14 \mathrm{CB}$ yang telah ditetapkan dengan surat keputusan (SK) sebagai cagar budaya. Kondisi ini tentu cukup mengkhawatirkan keamanan dan kelestarian CB yang belum di-SK-kan sebagai warisan budaya, apalagi mengingat tengah maraknya moderninasi infrastruktur di wilayah Sulawesi Tenggara. Di sisi lain, BPCP Makasar 
selaku instansi yang bertanggung jawab akan kelestarian CB, dihadapkan pada beberapa kendala, seperti kendala geografis, kuantitas SDM, dan kurangnya kolaborasi serta komunikasi dengan dinas terkait yang ada di wilayah Sulawesi Tenggara. Beberapa hal mendasar ini kemudian memunculkan tiga pertanyaan penting mengenai kondisi pelestarian CB di wilayah Sulawesi Tenggara, yakni;

1. Apa saja yang menjadi persoalan pelestarian $\mathrm{CB}$ di Sulawesi Tenggara,

2. Apa yang menjadi tantangan dan harapan pelestarian CB di Sulawesi Tenggara,

3. Bagaimana seharusnya konsep modernisasi infrastruktur yang sejalan dengan pelestarian $\mathrm{CB}$ di Sulawesi Tenggara.

Jawaban atas ketiga pertanyaan yang bersifat mendasar tersebut, selanjutnya akan diuraikan satu persatu dalam tulisan ini.

\section{B. Persoalan Pelestarian Cagar Budaya di wilayah Sulawesi Tenggara}

Pelestarian CB di Indonesia telah diupayakan dengan berbagai cara, baik dalam bentuk tindakan langsung (konservasi) maupun melalui jalur hukum (regulasi). Keduanya bersifat saling terkait dan mendukung satu sama lain. Pelestarian dalam bentuk konservasi diupayakan melalui tindakan langsung yang bersifat teknis dan metodologis, sedangkan melalui regulasi lebih pada penetapan peraturan perundangan yang bersifat mengikat dan pemberian sanksi bagi yang melanggar. Sejarah telah mencatat bawah kedua upaya ini telah dimulai jauh sebelum bangsa ini merdeka. Tepat di tahun 1862 pemerintah kolonial mendirikan Koninklijke Bataviaasch Genootschap van Kunsten en Watenschappen, yakni sebuah lembaga dibidang etnografi, seni, dan benda antik, sekaligus berperan sebagai museum yang dibentuk untuk kepentingan penelitian dan pelestarian cagar budaya wilayah jajahan (Supardi, 2004, Tanudirjo, 2003). Pihak kolonial juga mengeluarkan Monumenten Ordonnantie (MO) No.19 Tahun 1913 sebagai landasan hukum pelestarian cagar budaya. Pada perkembangannya, MO 1931 digantikan oleh Undang-Undang No. 5 Tahun 1992 Tentang Benda Cagar Budaya dan kemudian disempurnakan kembali dengan Undang-Undang No. 11 Tahun 2010 Tentang Cagar Budaya.

Dominasi peran negara dalam upaya pelestarian warisan budaya pada UU No. 5 Tahun 1992, menjadi salah satu alasan untuk kembali menyempurnakan undang-undang $\mathrm{CB}$ yang kemudian melahirkan UU No. 11 Tahun 2010 (Tanudirjo, 2003). Ruang lingkup CB dalam undang-undang baru juga tidak terbatas hanya pada benda buatan manusia, bergerak, atau tidak bergerak yang berupa kesatuan atau kelompok, akan tetapi semakin luas sehingga semakin melindungi warisan budaya di Indonesia yang begitu beragam. Hal ini jelas terlihat pada Pasal 1, UU No. 11 Tahun 2010 Tentang Cagar Budaya, menjelaskan bahwa yang dimaksud Cagar Budaya adalah warisan budaya bersifat kebendaan berupa Benda Cagar Budaya, Bangunan Cagar Budaya, Struktur Cagar Budaya, Situs Cagar Budaya, dan Kawasan Cagar Budaya di darat dan/atau di air yang perlu dilestarikan keberadaannya karena memiliki nilai penting bagi sejarah, ilmu pengetahuan, pendidikan, agama, dan/atau kebudayaan melalui proses penetapan.

Konsep dinamis yang dihadirkan dalam UndangUndang No. 11 Tahun 2010 Tentang Cagar Budaya dianggap cukup ideal dalam upaya pelestarian warisan budaya, namun di sisi lain konsep ini juga menghadirkan banyak hal baru yang cukup sulit untuk dipahami oleh masyarakat luas (Rahardjo, 2013). Beberapa hal baru yang cukup mencolok seperti misalnya sistem zonasi, model pemanfaatan yang melibatkan masyarakat, serta kewajiban pembentukan tim ahli cagar budaya dalam menentukan nilai penting dan usulan penetapan CB kepada pemerintah daerah. Persoalan lain yang cukup menimbulkan banyak permasalahan pelestarian khususnya di daerah adalah terkait belum diterbitkanya Peraturan Pemerintah (PP) dari UU No. 11 Tahun 2010 sebagai pedoman teknis dalam pelaksanaan pelestarian. Kasus terakhir terjadi di Kabupaten Lumajang - Provinsi Jawa Timur, dimana Peraturan Daerah (Perda) Cagar Budaya yang telah disahkan belum dapat berfungsi karena Peraturan Bupati (Perbup) selaku pedoman teknis belum dapat dikeluarkan dengan alasan menunggu keluarnya PP Undang-Undang CB No. 11 Tahun2010 (pedomannusantara.com. online: 5 Mei 2015).

Kasus yang terjadi di Lumajang hanyalah kepingan kecil dari persoalan besar pelestarian CB di Indonesia. Persoalan ini juga tidak mengenal kota besar ataupun kecil. Kota besar sekelas Semarang ternyata juga terlilit persoalan pelestarian Kawasan Kota Lama 
Semarang (KKLS), mulai dari masalah visi misi KKLS, meluapnya air laut (rob), hingga rumitnya masalah sosial yang terjadi disekitar KKLS (Kriswandhono, 2013). Wilayah lain yang juga mengalami persoalan pelestarian adalah Provinsi Sulawesi Tenggara (Sulawesi Tenggara). Wilayah Sulawesi Tenggara mulai dikenal potensi CB sejak era tahun 70-an, yakni dengan ditemukannya rock art/lukisan dinding goa pada goa-goa karst di Pulau Muna. Warisan budaya dari masa lalu yang melimpah di wilayah Sulawesi Tenggara tidak terbatas pada tinggalan masa prasejarah saja, namun terdapat beragam potensi lainnya mulai dari benteng tradisional, mesjid kuno, kawasan kota lama, bangkai kapal karam, serta tinggalan fasilitas pertahanan militer Jepang. Banyak di antara CB ini dalam kondisi rusak, terancam rusak maupun telah rata dengan tanah.

Secara umum, persoalan pelestarian dan rusaknya CB di Sulawesi Tenggara muncul dari tiga sumber utama yakni; 1) pemerintah/instansi terkait, 2) masyarakat, dan 3) lingkungan. Persoalan yang bersumber dari pemerintah lebih dikarenakan kurangnya kontrol/perhatian instansi terkait dibidang pelestarian (BPCB Makassar, Dinas Pariwisata dan Kebudayaan Provinsi dan Kab/Kota) dalam merespon kasus kerusakan/penghancuran CB yang terjadi di Sulawesi Tenggara. Adapun sumber persoalan yang muncul dari masyarakat lebih kepada kurangnya pemahaman/edukasi mengenai warisan budaya, atau tidak/belum mendapatkan penyuluhan terkait CB. Sedangkan sumber kerusakan akibat alam/ lingkungan bersifat kodrati/tidak dapat dihindari, namun bisa diperlambat dan dikurangi melalui jalan konservasi. Ketiga sumber kerusakan CB tersebut pada akhirnya memunculkan beberapa persoalan pelestarian cagar budaya di wilayah Sulawesi Tenggara yang apabila dikelompokkan berdasarkan penyebab kerusakannya adalah; 1) penghancuran, 2) vandalisme, 3) salah persepsI dalam tindakan konservasi, serta 4) penelantaran CB. Pembahasan keempat penyebab kerusakan CB di Sulawesi Tenggara selanjutnya dipaparkan pada uraian berikut.

1. Penghancuran CB

Kasus penghancuran bangunan cagar budaya (BCB) di wilayah Sulawesi Tenggara lebih cenderung terjadi di perkotaan, baik bangunan tunggal maupun yang tergabung dalam satu kawasan. Kecenderungan ini muncul dikarenakan sifat-sifat dari Kota Kendari itu sendiri; padat penduduk dengan beragam latarbelakang, serta sangat tertarik dengan budaya baru atau modernisme. Kota Kendari beberapa tahun belakangan ini terlihat sibuk dengan gaya hidup baru dan modernisme. Kecenderungan ini ditandai pada maraknya pembangunan infrastruktur pendukung modernisasi seperti mall, hotel, ruko, café, maupun fasilitas lainnya. Bangunan lama yang dianggap tidak modern dan ketinggalan zaman digantikan dengan bangunan baru. Sulit untuk memungkiri bahwa apa yang terjadi di Kendari juga hampir terjadi diseluruh kota-kota lain di Indonesia. Daud Aris Tanudirjo selaku pakar pelestarian CB di Indonesia melihat bahwa, masyarakat kota dengan ciri kehidupan materialis dan konsumtif, sumberdaya yang memiliki nilai sejarah, kebudayaan, dan ilmu pengetahuan dengan mudah dapat dikorbankan untuk kepentingan komersial semata. Karena itulah sumberdaya budaya sangat rawan menghadapi kehancuran, dengan mengatasnamakan dinamika perkembangan kota (Tanudirjo, 2006).

Tepat pada 7 Februari 2015, terjadi penghancuran Kota Lama Kendari hingga rata dengan tanah dengan alasan pembangunan jembatan Bahteramas yang menghubungkan Kecamatan Kendari dengan Kecamatan Abeli. Kedua kecamatan ini dipisahkan oleh teluk Kendari (teluk Vosmaer), walaupun demikian keduanya tetap terhubung melalui jalan by pass dua arah yang terbentang sepanjang pesisir teluk Kendari. Jarak tempuhnya juga relatif singkat, yakni \pm 20 menit dengan tingkat kemacetan mendekati zero. Alasan penghancuran kawasan kota lama ini jelas berdalih peningkatan PAD dan ekonomi masyarakat melalui akses penghubung yang baik. Mega proyek jembatan Bahteramas senilai 540 Milyar, apabila dilihat dari tiga landasan sederhana; 1) jumlah penduduk Kota Kendari \pm 315 ribu jiwa dengan tingkat kemacetan lalu lintas yang rendah, 2) telah tersedianya jalur darat penghubung dua kecamatan, 3) tersedianya lokasi lain di sekitar kota lama yang bisa dijadikan lokasi pembangunan jembatan, tentu tidak perlu menghancurkan kawasan bersejarah Kota Lama Kendari seluas $\pm 1,5$ ha dengan \pm 81 bangunan kolonial di dalamnya. Disebut kota lama, karena memang kawasan inilah yang menjadi cikal bakal kota Kendari dengan segala fasilitasnya (loji, pelabuhan, gudang VOC, pecinan, bioskop pertama Kendari, sekolah cina, dll) yang berdasarkan arsip sejarah mulai dibangun 


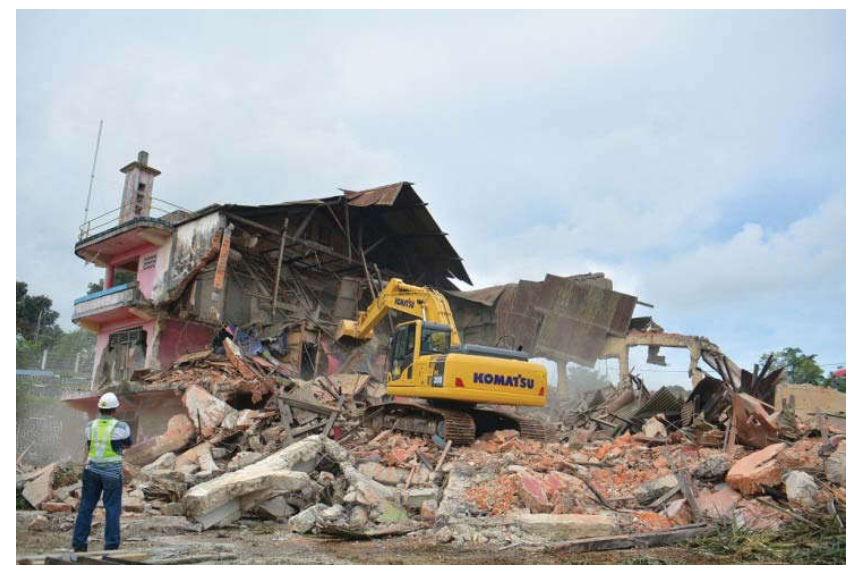

Foto 1. Penghancuran Kendari Teater di Kawasan Kota Lama Kendari.(Dok: Nur Ihsan D)

menjadi kota pelabuhan dagang dan pangkalan militer oleh Vosmaer pada tahun 1832 (Rabani, 2010: 60).

Penghancuran kawasan kota lama ini cukup mengejutkan masyarakat Kota Kendari khususnya komunitas yang peduli dengan sejarah dan cagar budaya. Beberapa komunitas pelestari telah berupaya melakukan tindakan negoisasi dengan pihak pemerintah, namun tidak membuahkan hasil. Musibah ini terjadi bukan karena tidak ada kelompok masyarakat yang peduli dan mencoba mengadvokasi, namun lebih dikarenakan tidak adanya kajian akademis yang memadai serta rekomendasi dari Tim Ahli CB yang mampu menguatkan pernyataan bahwa kawasan ini adalah kawasan bersejarah dan bangunan cagar budaya yang harus ditetapkan/di-SKkan pemerintah daerah sebagai kawasan CB. Langkah ini sejalan dengan amanat UU No. 11 Tahun 2010, BAB IV pasal 28, 29, dan 30 mengenai kewenangan pemerintah daerah untuk mendaftarkan, menetapkan serta memeringkat artefak/bangunan/kawasan yang diduga/ berpotensi sebagai CB sesuai rekomendasi Tim Ahli CB. Akibat dari kelalaian ini, kini Kota Lama tinggal nama, dan sebentar lagi akan digantikan tiang-tiang pancang jembatan raksasa. Apa sebaiknya wilayah ini juga harus berganti nama? Tidak lagi kita sebut kota lama, tapi kota jembatan baru.

\section{Vandalisme pada CB}

"Andi, Iwan, Anto pernah kesini" tulisan semacam ini, atau dalam bentuk lain tentu pernah kita lihat pada candi, benteng, baterai, pillbox Jepang maupun Bangunan Cagar Budaya (BCB) lainnya. Para ahli psikologi beranggapan bahwa tindakan ini adalah

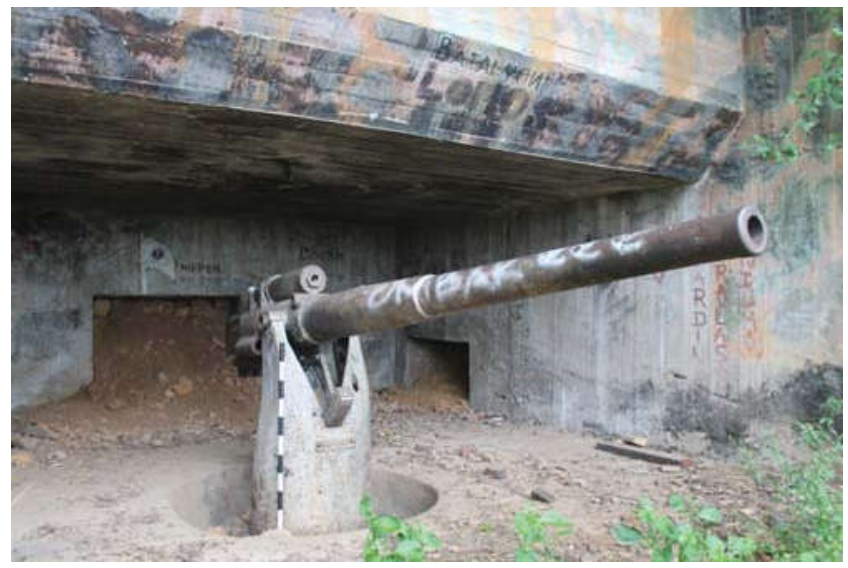

Foto 2.Baterai Mata di Kelurahan Mata-Kota Kendari.

bentuk dari pernyataan eksistensi diri pelaku pencoretan (vandalism) kepada orang lain. Di wilayah Kota Kendari terdapat beberapa pillbox (tempat perlindungan dan menembak berukuran kecil yang dibangun pasukan Jepang) dan baterai (bangunan pertahanan berukuran kecil yang berdiri sendiri dengan dilengkapi meriam/ senjata) yang mengalami vandalism. Pillbox dan baterai ini tersebar di wilayah Lepo-Lepo, Jl Ahmad Yani, dan Jl. Made Sabara, Kelurahan Mata, dan Ambepua. Jumlah pasti pillbox dan baterai di wilayah Kota Kendari belum dapat diketahui, namun diperkirakan lebih dari 100 yang tersebar di beberapa lokasi. Pada beberapa dindingnya banyak terdapat coretan-coretan baik dari spidol, pilox, maupun cat dengan beragam kalimat.

Kecenderungan terjadinya vandalisme pada beberapa pillbox dan baterai di wilayah Kota Kendari kemungkinan besar dipicu karena kurangnya pengawasan, perhatian, pengamanan terhadap CB. Sejauh ini, pillbox dan baterai belum didaftarkan/ditetapkan sebagai CB. Kemungkinan tindakan vandalism akan terus terjadi dan semakin mengotori CB. Langkah kongkrit pelestarian perlu segera dilakukan dengan mendata, mendaftarkan, mengkaji, merekomendasikan melalui Tim Ahli CB dan menetapkannya melalui SK sebagai CB oleh pemerintah Kota Kendari.

\section{Salah persepsi dalam konservasi CB}

'Salah persepsi' mungkin kata yang tepat untuk mewakili ketidakpahaman, rendahnya pengetahuan, salah metode, dan terjadinya pelanggaran prinsip dan etika konservasi yang mengakibatkan kerusakan baik sebagian maupun keseluruhan pada CB. Kasus seperti ini telah 


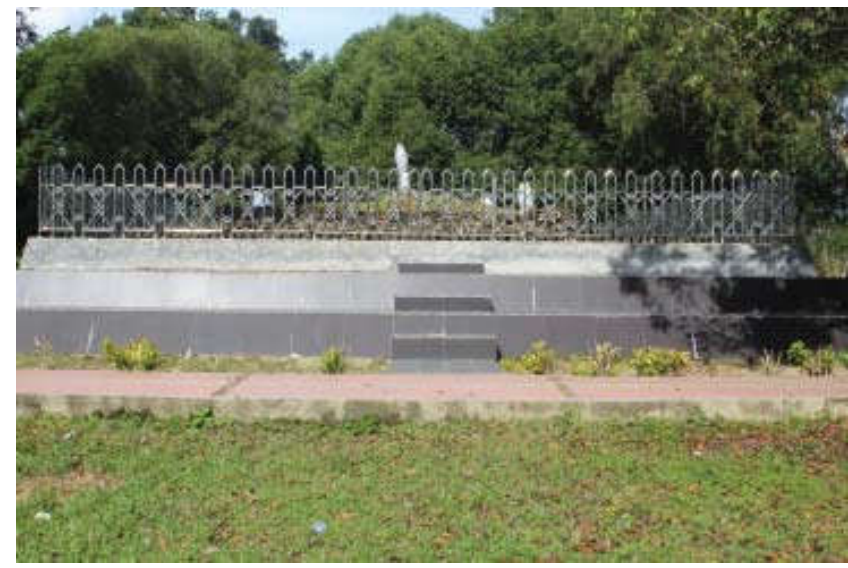

Foto 3. Makam Raja Lakidende,di Unahaa Kabupaten Konawe.

banyak terjadi, termasuk di wilayah Provinsi Sulawesi Tenggara. Adapun contoh kasusnya dapat dilihat pada makam Raja Sao-Sao di Kota Kendari, dan makam Raja Lakidende di Unahaa Kabupaten Konawe. Kedua makam raja yang memiliki nilai penting kesejarahan, identitas, maupun arkeologis ini telah mengalami perubahan bentuk yang sangat signifikan yang dilakukan oleh pemerintah setempat dengan dalih pelestarian. Masalah tidak akan muncul apabila konservasi dilakukan oleh pihak yang kompeten, sesuai metode, prinsip dan etika konservasi $\mathrm{CB}$, namun justru sebaliknya hingga mengubah bentuk asli makam secara permanen. Kurangnya koordinasi antara stakeholder bidang terkait serta belum terdaftar dan ditetapkannya kedua makam ini pada registrasi nasional sebagai CB menjadi pemicu terjadinya salah persepsi dalam konservasi kedua CB yang cukup penting bagi masyarakat Sulawesi Tenggara.

\section{CB yang ditelantarkan}

Di sekitar kawasan kota lama Kendari akan banyak kita jumpai bangunan dari masa kolonial dalam kondisi yang cukup mengkhawatirkan, misalnya, bekas gudang pelabuhan, sekolah Cina, dan rumah jabatan pertama Gubernur Sulawesi Tenggara. Tampilan fisik bangunan ini dalam kondisi kotor dan tidak terurus. Bangunan-bangunan ini dalam kondisi tidak digunakan, atau tidak dihuni. Sehingga semakin mempercepat kerusakan pada bangunan dan terlihat kusam. Secara kontekstual, bangunan-bangunan ini erat kaitannya dengan keberadaan kota lama Kendari sebagai cikal bakal lahirnya kota modern Kendari seperti saat ini. Apabila kondisi ini dibiarkan terus berlanjut, maka tidak menutup

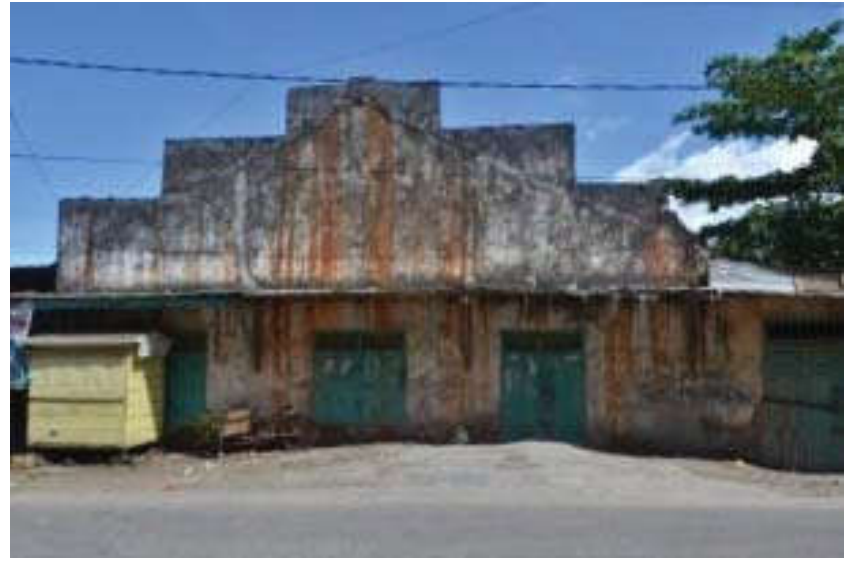

Foto 4.Gudang pelabuhan. Dok: Balar Makassar, 2012

kemungkinan dalam beberapa tahun kedepan bangunan ini juga akan diratakan dan digantikan bangunan baru. Contoh kasus lainnya dapat ditemui di Pulau Wawonii, dan Pulau Muna yang banyak memiliki benteng tradisonal ( \pm 15 benteng) yang terlantar hingga rimbun tertutup alang-alang dan semak belukar. Penanggulan penyelamatan serta penelitian perlu segera dilakukan demi kelestarian CB tersebut.

\section{Kurang Perawatan}

Terdapat \pm 6 goa prasejarah yang menyimpan potensi berupa rock art di wilayah Pulau Muna yang pada tahun 2003 telah di-SK-kan oleh Menteri Kebudayaan dan Pariwisata, I Gede Ardika dengan nomor SK: KM.8/ PW.007/MKP-03, tanggal 4 Maret 2003. Kondisi terkini situs terlihat kurang perawatan, lemah pengawasan, dan rawan vandalisme serta bentuk pengerusakan lainnya. Tingkat kelembaban yang tinggi, aktifitas masyarakat dan pengunjung yang tidak terkontrol, serta belum pernah dilakukannya tindakan konservasi pada rock art, berakibat semakin memudarnya rock art pada beberapa goa. Pelestarian situs tidak selesai hanya dengan menempatkan Jupel (juru pelihara) di situs, namun perlu tindakan pengawasan rutin, konservasi, penelitian lanjut, serta edukasi kepada publik mengenai keberadaan dan sifat situs yang rentan terhadap kerusakan.

\section{Tantangan dan Harapan Pelestarian Cagar Budaya di Sulawesi Tenggara}

Provinsi Sulawesi Tenggara ditinjau dari letak geografisnya tepat berada di jalur pintu masuk menuju kawasan Indonesia Timur. Posisi strategis ini juga disadari 
sepenuhnya oleh Vosmaer, sehingga meminta kepada pemerintah pusat Hindia-Belanda di Batavia untuk menjadikan Teluk Kendari sebagai pelabuhan dagang dan pangkalan militer. Dimasa pendudukan Jepang, wilayah ini juga dianggap memiliki banyak aset penting sehingga militer Jepang banyak membangun lubang pertahanan, pillbox, lapangan terbang, baterai, dan fasilitas militer lainnya di wilayah Sulawesi Tenggara. Latarbelakang historis ini menjadikan wilayah Sulawesi Tenggara kaya akan tinggalan kolonial Belanda-Jepang dalam beragam bentuk artefak. Beranjak ke masa yang lebih jauh ke belakang, wilayah Sulawesi Tenggara oleh beberapa ahli prasejarah dianggap sebagai jembatan persebaran ras dan budaya Austronesia menuju kawasan Indonesia Timur. Temuan di lapangan memperlihatkan adanya kemiripankemiripan pada seni lukis batu cadas atau rock art, teknik dan motif hias gerabah, pola-pola penguburan, serta pengolahan bahan makanan berbahan sagu. Sebaran goa prasejarah dapat kita temui mulai dari wilayah Konawe hingga Konawe Utara, Kolaka hingga ke Bombana, Pulau Muna hingga Pulau Wawonii. Berdasarkan carbon dating atau uji karbon untuk menentukan usia penghunian yang pernah dilakukan pihak Balai Arkeologi Makassar, diperkirakan goa-goa ini mulai dihuni pada kurun waktu 17.000 hingga 8000 BP (LPA Balar Makassar, 2012).

Sebagian besar dari ratusan situs, artefak, maupun bangunan cagar budaya yang terdapat di wilayah Sulawesi Tenggara telah mengalami kerusakan, bahkan banyak diantaranya mengalami kepunahan. Beberapa persoalan yang pada bab sebelumnya penulis paparkan hanyalah contoh kecil dari gambaran umum permasalahan pelestarian di wilayah Sulawesi Tenggara, namun fakta di lapangan ada ratusan CB yang terancam rusak dan punah. Kondisi ini tercipta oleh beberapa faktor yang bersumber dari pemerintah, masyarakat, akademisi, atau dengan kata lain tercipta dari kita. Tentu ini menjadi tantangan besar untuk kita pecahkan dan tuntaskan bersama-sama demi terciptanya kelestarian warisan budaya bangsa di wilayah Sulawesi Tenggara. Berpijak pada pola-pola penyebab kerusakan CB dan kondisi sosial dan politik di Sulawesi Tenggara, maka dapat dirumuskan beberapa tantangan yang perlu dituntaskan bersama, yakni;

1. Undang-undang $\mathrm{CB} /$ Perda $\mathrm{CB} / \mathrm{PP} /$ Perwal

Pasal 96 UU No. 11 Tahun 2010 tentang Cagar Budaya, memberikan kewenangan yang cukup besar kepeda pemerintah daerah untuk mengelola $\mathrm{CB}$ yang dimilikinya. Menindaklanjuti amanat UU CB tersebut, maka pada tahun 2013 Pemerintah Kota Kendari mengeluarkan Perda Cagar Budaya No. 21 Tahun 2013 tentang Cagar Budaya Kota Kendari. Beragam aturan mengenai pelestarian $\mathrm{CB}$ tertuang dalam pasal-pasalnya dan cukup mengayomi, melindungi, dan melestarikan CB di Kota Kendari. Beberapa pasal diantaranya diatur lebih lanjut dengan Peraturan Walikota (Perwal) sebagai pedoman teknis lapangan. Dua tahun berselang setelah UU No.21 Tahun 2013 disahkan, Perwal yang mengatur pedoman pelaksanaan teknis belum dikeluarkan. Kondisi ini penulis ibaratkan seperti macan ompong yang tidak bisa berbuat apa-apa, sebatas hanya jadi pajangan dan bahan diskusi. Dilain sisi, Pemerintah Provinsi Sulawesi Tenggara hingga saat ini belum mengeluarkan Perda CB setingkat provinsi yang seyogyanya menjadi payung dan contoh bagi pemerintah daerah Kab/Kota di Sulawesi Tenggara. Persoalan ini bersifat sangat prioritas, juga mendesak sehingga tidak ada kata lain selain harus segara kita tuntaskan bersama.

2. Tim Ahli CB

UU No. 11 Tahun 2010 tentang Cagar Budaya pada pasal 31 menginstruksikan untuk membentuk Tim Ahli CB guna melakukan pengkajian terhadap objek yang diduga $\mathrm{CB}$ untuk selanjutnya direkomendasikan kepada pemerintah daerah dan ditetapkan melalui SK sebagai CB. Perda CB Kota Kendari BAB IV Pasal 4, ayat (2) untuk melaksanakan tugasnya, pemerintah daerah berwenang; membentuk Tim Ahli CB.Selanjutnya pada BAB V Pasal 5, lebih dipertegas lagi mengenai pembentukan Tim Ahli CB. Peran penting tim ahli dalam pelestarian $\mathrm{CB}$ terletak pada keahlian dan pengetahuannya dalam bidang $\mathrm{CB}$ sehingga dapat membedakan yang mana $\mathrm{CB}$ atau bukan, dan mampu melihat nilai-nilai penting yang terkandung dalam $\mathrm{CB}$, apakah bersifat nasional, skala provinsi, atau hanya kabupaten/kota. Walaupun dalam Perda No. 21 Tahun 2013 telah diinstruksikan membentuk Tim Ahli, namun hingga saat ini tim itu belum ada, sehingga banyak CB yang belum terlindungi dengan SK Cagar Budaya. Dari hasil survei $\mathrm{CB}$ yang dilakukan penulis di wilayah 
Sulawesi Tenggara, terdapat $\pm 200 \mathrm{CB}$ yang memiliki nilai penting skala provinsi, namun satu pun belum ada yang terdaftar dan di-SK-kan. Kondisi CB tanpa SK ini apabila tidak segera ditindaklanjuti akan berdampak pada pengrusakan, penghancuran, pencurian, dan kepunahan karena tidak terawat.

3. Perencanaan Rencana Tata Ruang Wilayah yang propelestarian CB

Berdasarkan Peraturan Pemerintah No. 26 Tahun 2008 tentang Pedoman Rencana Tata Ruang Wilayah Nasional (RTRW Nasional), penataan ruang adalah suatu sistem proses perencanaan tata ruang, pemanfaatan ruang, dan pengendalian pemanfaatan ruang. Penataan ruang ini wajib dilakukan seluruh daerah provinsi dan kabupaten kota di Indonesia sesuai pedomannya, yakni Peraturan Menteri Pekerjaan Umum No. 15 Tahun 2009. Isi dari Pedoman RTRWP (tingkat provinsi) juga mengatur mengenai kawasan strategis meliputi kawasan budaya yang mengandung CB. Kasus dibeberapa daerah termasuk wilayah Provinsi Sulawesi Tenggara, RTRWP hingga hari ini masih dalam proses penyusunan. Harapannya para pembuat RTRWP Sulawesi Tenggara dalam perencanaan kawasan budaya dengan tinggalan CB telah mengkonsultasikannya kepada pihak yang kompeten mengenai kawasan $\mathrm{CB}$ terkait perlindungan, pengembangan dan pemanfaatannya. Apabila belum, diharapkan mengkonsultasikannya kembali sehingga RTRWP dan RTRW/K/K di seluruh daerah Sulawesi Tenggara benar-benar pro-pelestarian $\mathrm{CB}$ yang mampu melindungi, melestarikan, memanfaatkan, dan mengembangkan CB sesuai amanat UU No. 11 Tahun 2010.

4. Edukasi masyarakat di daerah mengenai $\mathrm{CB}$ Pengalaman penulis dalam penelitian arkeologi kebeberapa wilayah kabupaten dan kota di Sulawesi Tenggara menyimpulkan, bahwa rata-rata masyarakat di daerah tidak mengetahui dan memahami apa itu CB, UU No. 11 Tahun 2010, nilai penting CB, sanksi pelanggaran terhadap $\mathrm{CB}$, maupun upaya pelestarian dan pemanfaatan yang bisa dilakukan terhadap CB di wilayahnya. Banyak faktor penyebab kurang teredukasinya masyarakat di daerah mengenai $\mathrm{CB}$ di sekitarnya, misalnya; sulitnya akses transportasi, minimnya SDM, minimnya anggaran edukasi mengenai $\mathrm{CB}$, tidak terdistribusikannya buku UU No. 11 Tahun 2010 pada masyarakat di daerah, maupun belum muncul itikad baik dan keseriusan dari stakeholder terkait.

Contoh kasus kurang teredukasinya masyarakat di daerah dapat dilihat pada masyarakat Kecamatan Wiwirano Kabupaten Konawe Utara yang penulis kunjungi pada Februari 2015. Kecamatan Wiwirano dengan potensi goa-goa karst Wawontoahu (berjumlah \pm 90 goa) yang pernah dimanfaatkan masyarakat pra-sejarah, banyak menjarah tempayan, guci naga, keramik Vietnam dan Cina, gelang perunggu yang kemudian dijual kepada kolektor. Lemahnya pengetahuan dan pemahaman masyarakat Wiwirano mengenai CB berikut sanksinya menjadi faktor utama rusaknya situs pra-sejarah di kawasan goa karst Wawontoahu. Sekali lagi kita diingatkan betapa pentingnya edukasi $\mathrm{CB}$ pada masyarakat dan kita juga ditegur bahwa kegiatan-kegiatan arkeologi publik di Indonesia belum berjalan dengan baik.

5. Upaya-upaya riset dan konservasi CB.

Wilayah Provinsi Sulawesi Tenggara tergolong kaya akan $\mathrm{CB}$, baik dari masa prasejarah, Islam, maupun kolonial. Penelitian terakhir yang dilakukan penulis di wilayah Lanud Wolter Mongonsidi Kecamatan Ranometo seluas 1500 ha, mengungkap kawasan pertahanan Jepang dengan fasilitas militer \pm 70 temuan (pillbox, baterai, bunker, dan fasilitas pendukung militer lainnya). Kawasan militer Jepang ini sebelumnya telah dikunjungi Balar Makassar di tahun 2012 dengan hasil \pm 25 temuan (pillbox, baterai, bunker dan fasilitas lain). Sejauh pengamatan penulis, masih banyak fasilitas militer Jepang lainnya yang tersembunyi dibalik lebatnya hutan Ranemeeto. Kurangnya penelitian di wilayah Sulawesi Tenggara karena tidak didukung oleh SDM yang memadai serta minimnya perhatian pemerintah daerah pada kajiankajian arkeologi, dan hal ini juga berlaku pada ranah konservasi. Leang Kabori, Wabose, Metanduno, dan Toko, adalah goa prasejarah yang cukup terkenal diwilayah Sulawesi Tenggara dengan lukisan-lukisan berwarna coklat yang banyak menampilkan aktifitas sehari-hari leluhur masyarakat Sulawesi Tenggara dimasa lalu. Kurangnya penjagaan, kelembaban 
udara, serta tidak adanya upaya konservasi terhadap lulisan-lukisan pada dinding goa ini, mengakibatkan terjadinya kerusakan yang cukup mengkhawatirkan. Sejak diteliti pertama kali oleh E.A Kosasih ditahun 70-an, hingga saat ini belum pernah dilakukan konservasi lukisan-lukisan yang terdapat pada Leang (goa) Kabori, Wabose, Metanduno, Toko, dan beberapa leang lainnya yang telah ditetapkan dsebagai CB dengan SK No: KM.8/PW.007/MKP03, tanggal 4 Maret 2003. Masih banyak contoh kasus lain yang tidak bisa penulis paparkan dalam tulisan singkat ini, namun pada intinya upaya riset dan konservasi CB di wilayah Sulawesi Tenggara mendesak untuk segera ditindaklanjuti.

6. Pemanfatan $\mathrm{CB}$ untuk kesejahteraan masyarakat Dari ratusan jumlah CB di Sulawesi Tenggara, sejauh ini dampak langsung pemanfaatan CB yang dirasakan masyarakat baru terjadi di Benteng Wolio Kesultanan Buton di Kota Bau-bau. Pemerintah daerah Kota Bau-Bau mengelola Benteng Wolio sebagai kawasan wisata yang menghadirkan paket budaya yang cukup menarik dan dikemas kreatif. Pemanfaatan benteng ini telah menarik wisatawan domestik maupun asing untuk berkunjung dan tinggal beberapa saat di rumah-rumah tradisonal masyarakat Buton yang terletak di dalam benteng. Kios-kios souvenir pun bermunculan, demikian juga dengan warung-warung makanan khas Buton bisa kita temukan di dalam kawasan benteng seluas \pm 26 ha. Tantangannya adalah terdapat ratusan benteng lain yang tersebar di wilayah Provinsi Sulawesi Tenggara, puluhan benteng di Pulau Muna, Wawonii, Buton Utara, Wakatobi, maupun di Kendari daratan. Tidak mengherankan apabila wilayah ini diberi julukan negeri seribu benteng. Benteng-benteng ini akan sangat menarik apabila dikemas dalam konsep open air museum seperti yang telah diterapkan di beberapa wilayah di Eropa dan India. Khusus untuk goa-goa prasejarah dan peninggalan-peninggalan kesultanan Buton dan Kerajaan Konawe bisa dikemas dalam konsep eco museum dan wisata sejarah. Masyakarat tentu akan menikmati manfaat langsung dari pemanfaatan CB ini, baik segi ekonomi, wawasan, maupun tumbuhnya rasa bangga akan budaya dan identitasnya. Hal ini juga akan membawa manfaat pada $\mathrm{CB}$, yakni dicintai dan lestari hingga seribu tahun lagi.

Dibalik segala persoalan dan tantangan pelestarian di Wilayah Sulawesi Tenggara, masih ada titik terang pemberi harapan yang akan membawa CB di seluruh wilayah Sulawesi Tenggara menuju kata lestari dan memberi manfaat bagi masyarakatnya. Bagi sebagian kalangan mungkin menganggapnya bukan bagian dari jawaban atas persoalan pelestarian di Sulawesi Tenggara, namun bagi penulis beberapa poin ini merupakan titik terang menuju kebangkitan pelestarian di wilayah Sulawesi Tenggara. Poin-poin pembawa harapan ini ada yang berbentuk institusi, SDM, regulasi, dan kegiatan, yakni sebagai berikut.

1. Jurusan Arkeologi Universitas Halu Oleo

Berdasarkan SK pendirian Program Studi yang dikeluarkan Dirjen Pendidikan Tinggi No. 677/E. E2/DT/2013, secara resmi di tahun 2013 Program Studi Arkeologi Universitas Halu Oleo menerima mahasiswa baru angkatan pertamanya. Minimnya tenaga pengajar berlatar belakang pendidikan arkeologi tidak menggoyahkan niat baik dan langkah kemajuan ini. Diperkuat dengan tiga dosen pengajar arkeologi, serta dibantu beberapa dosen dari bidang keilmuan lain. Prodi yang baru berumur dua tahun itu kini telah berubah jadi jurusan dan telah berakreditasi B dari Ban PT. Apresiasi masyarakat Sulawesi Tenggara sangat baik untuk jurusan baru ini, terbukti dari penerimaan pertama di tahun ajaran 2013/2014 telah terjaring sebanyak 45 mahasiswa, dan ditahun ajaran 2014/2015 sebanyak 98 mahasiswa. Diperkirakan untuk tahun ajaran baru 2015/2016 peminat mencapai 60 pendaftar. Selama proses pendidikan yang telah berlangsung dua tahun, mahasiswa Arkeologi Universitas Halu Oleo telah melakukan beberapa kegiatan penelitian; kajian prasejarah di goa-goa Wiwirano, kajian arkeologi Islam di Pulau Buton, kajian strategi militer Jepang di Ranomeeto, serta kajian konservasi keramik, logam dan kayu di Museum Provinsi Sulawesi Tenggara. Jurusan Arkeologi juga aktif berpartisipasi dalam kegiatan arkeologi berskala nasional; Penelitian Arkeologi Terpadu Indonesia (PATI) III di Trowulan, PIAMI di Makasar, serta kajian konservasi batu Candi Borobudur. Tidak hanya itu, Jurusan 
Arkeologi UHO juga aktif mengadakan kuliah umum yang mendatangkan pemateri dari berbagai instansi arkeologi di Indonesia; Jurusan Arkeologi UNHAS, BPCB Makassar, Balai Arkeologi Makassar, serta Universitas De la Rochelle Perancis. Kegiatan-kegiatan tersebut menjadi suplemen pendukung mahasiswa Arkeologi UHO untuk menempa dan melatih diri menjadi arkeolog sejati. Tiga tahun kedepan, instansi ini akan melahirkan arkeolog-arkeolog handal dan professional yang mampu meneliti, melindungi, melestarikan, mengembangkan, dan merancang pemanfaatan sumber daya arkeologi di Sulawesi Tenggara untuk kesejahteraan masyarakat.

2. Perda No. 21 Tahun 2013 Tentang Cagar Budaya Kota Kendari

Pemerintah Kota Kendari bekerjasama dengan Fakultas Hukum Universitas Halu Oleo merancang peraturan daerah tentang cagar budaya. Kegiatan ini dilaksanakan atas dasar kesadaran akan keberadaan CB di wilayah Kota Kendari banyak yang terancam rusak. Hal positif ini disambut baik DPRD kota Kendari yang kemudian mengesahkannya sebagai Perda No. 21 Tahun 2013 Tentang Cagar Budaya Kota Kendari. Sifat dari Perda ini adalah melindungi, mengayomi, serta memfasilitasi segala bentuk pelestarian CB. Kata 'ideal' memang sulit untuk diraih, khususnya pada persoalan pelestarian. Dua tahun perjalanannya setelah disahkan, hingga saat ini Perwal (Peraturan Walikota) sebagai pedoman teknis UU No. 21 Tahun 2013 belum juga diterbitkan. Sejauh ini sepak terjang UU No. 21 Tahun 2013 memang belum terlihat, walaupun demikian, setidaknya Perda ini telah membawa harapan dan semangat baru bagi pelestarian CB di wilayah Kota Kendari.

3. Sosialisasi pendaftaran $\mathrm{CB}$

Langkah-langkah kongkrit pelaksanaan isi pasalpasal dalam UU No. 11 Tahun 2010 pada tahun 2015 ini semakin terlihat di beberapa wilayah Indonesia. Tepat pada bulan Mei tahun 2015 silam, pihak Direktorat Pelestarian Cagar Budaya dan Permuseuman (Dit. PCBM) melaksanakan sosialisasi regitrasi CB yang bertempat di Hotel Swissbell Kendari, Sulawesi Tenggara. Kegiatan ini mengundang seluruh instansi terkait di jajaran Provinsi Sulawesi Tenggara, tokoh adat, serta dari pihak akademisi. Para peserta yang hadir diberikan edukasi mengenai proses dan prosedur pendaftaran/ registrasi CB yang tertuang pada Bab VI pasal 28, 29, dan 30. Pihak pelaksana yakni Dit. PCBM juga menekankan agar segera dibentuk tim register serta tim ahli CB tingkat provinsi dan kab/kota. Kegiatan ini tentu membawa harapan baru bagi pelestarian CB di Sulawesi Tenggara yang beberapa tahun belakangan ini sedang tertidur pulas. Para stakeholder dan pemangku kebijakan terkait pelestarian $\mathrm{CB}$ di Sulawesi Tenggara seakan-akan ditegur dan diingatkan akan tanggungjawabnya dan banyaknya persoalan pelestarian yang harus dituntaskan. Andaikata kegiatan serupa diteruskan kembali oleh pemerintah daerah Sulawesi Tenggara pada tataran dinas terkait dan masyarakat dimasing-masing kab/ kota, tentu kesadaran pelestarian disegenap lapisan masyarakat akan semakin terwujud.

4. Pelatihan konservasi staf BPCB di Borobudur Kegiatan Bimbingan Teknis (Bimtek) konservasi CB staf BPCB seluruh Indonesia yang diselanggarakan di Balai Konservasi Borobur memang telah berlangsung sejak beberapa tahun yang lalu.Tahun ini kegiatan diklat berlangsung dari 18 April - 27 April 2015, dan mengundang seluruh staf BPCB termasuk BPCB Makassar. Kegiatan ini tentunya akan menambah pengetahuan dan keahlian staf BPCB Makassar dalam tindakan konservasi CB, sehingga akan mampu menangani berbagai kasus konservasi yang ada diwilayah kerjanya termasuk kasus-kasus kerusakan CB yang ada di Provinsi Sulawesi Tenggara. Kegiatan bimtek ini merupakan agenda positif yang sangat bermanfaat, khususnya bagi daerah-daerah. Harapannya untuk ke depan, kiranya peserta bimtek konservasi CB tidak hanya dari kalangan BPCB saja, namun juga melibatkan staf dinas terkait pelestarian $\mathrm{CB}$ di daerah, serta para praktisi pelestarian. Tentunya $\mathrm{CB}$ di daerah akan semakin lestari dan terkonservasi apabila di daerahnya memiliki SDM bidang konservasi yang memadai secara kualitas dan kuantitas. Mengingat CB di daerah berjumlah begitu banyak dan tersebar pada wilayah yang luas, maka tugas dan tanggung jawab 
pelestarian $\mathrm{CB}$ tidak bisa hanya ditopang oleh $\mathrm{BPCB}$, namun harus melibatkan seluruh stakeholder terkait yang ada di daerah. Kegiatan bimtek konservasi CB ini, tentu membawa titik terang dan harapan bagi pelestarian di daerah, khususnya wilayah Provinsi Sulawesi Tenggara.

5. Museum Provinsi Sulawesi Tenggara dan Museum Wallace UHO

Mensch (2003), menyebutkan bahwa pada dasarnya museum memiliki tiga fungsi dasar; yakni melakukan tindakan preservasi, penelitian, dan komunikasi. Preservasi dalam hal ini dapat diartikan sebagai suatu bentuk perlindungan, konservasi, dan pelestarian terhadap CB. Benda cagar budaya yang telah menjadi koleksi museum kemudian diteliti, dan hasilnya akan dikomunikasikan kepada pengunjung dengan cara-cara tertentu yang menarik dan kreatif. Ketiga fungsi dasar ini juga dilaksanakan oleh pihak Museum Provinsi Sulawesi Tenggara. Benda cagar budaya yang disimpan oleh masyarakat dipreservasi, diteliti, dan dikomunikasikan oleh pihak museum kepada masyarakat. Keberadaannya di tengahtengah masyarakat Sulawesi Tenggara memiliki peranan penting dalam upaya-upaya pelestarian $\mathrm{CB}$ khususnya yang berbentuk tangible atau kebendaan. Sinar terang pelestarian di Sulawesi Tenggara semakin terlihat saat didirikannya Museum Wallacea oleh pihak Universitas Halu Oleo pada tahun 2013 yang lalu. Keberadaannya akan menambah ruang perlindungan CB diwilayah Sulawesi Tenggara, serta menjadi media edukasi dan penyadaran masyarakat untuk lebih peduli terhadap warisan budaya.

\section{Menjadi Modern Tanpa Kehilangan Identitas}

'Time changes everything to be art. Objek yang kini kita sebut sebagai $\mathrm{CB}$, semula merupakan objek yang dapat dimaknai dan difungsikan masyarakat pendukungnya, kemudian oleh waktu dan modernisasi telah mengubahnya menjadi sesuatu yang berbeda. Waktu menjadikannya menjadi suatu objek yang langka, bersifat terbatas, dan memiliki nilai-nilai penting sehingga patut dijadikan warisan budaya. Proses transformasi ini telah membawa warisan budaya baik dalam bentuk benda, bangunan, struktur, situs maupun kawasan kedalam zona merah yang rentan terhadap konflik, pengerusakan, dan kepunahan. Menjawab persoalan dan tantangan ini, negara sebagai lembaga pelaksana pemerintahan mengambil peran aktif dalam penyelamatan, pelestarian, dan pengembangan melalui perundangan, unit pelaksana di lapangan (BPCB, BALAR, dinas terkait), dana anggaran, serta dukungan dalam bentuk lain. Hal ini senada dengan pemikiran Mizoguchi (2007), yang berpendapat bahwa negara harus mengambil peran sebagai penghubung antara keberadaan warisan budaya di masa lalu dengan masa kini, dan menjadikannya sebagai penguat identitas kebangsaan yang semakin luntur oleh globalisasi dan modernisasi.

Globalisasi dan modernisasi itu pasti terjadi, dan tidak dapat dihindari seperti halnya penuaan pada manusia. Efek positif dan negatif yang muncul dari proses globalisasi dan moderninasi juga juga tidak dapat dihindari, namun dapat dikontrol dan dikelola sesuai arah yang dinginkan. Apabila kita tarik pada kasus CB, maka untuk mengontrol efek negatif dari globalisasi dan moderninasi, alat kontrol yang digunakan bisa berupa regulasi/perundangan, edukasi, aksi (dalam bentuk penelitian, konservasi, penetapan, pengembangan, dan pemanfaatan CB), dan evaluasi. Pemerintah memiliki peran penting dalam merancang, menerapkan serta melakukan evaluasi terhadap alat kontrol ini. Alat kontrol ini bisa berupa regulasi, SDM, museum, UPT, SK-CB, kegiatan sosialisasi dan dalam bentuk lainnya yang sifat dan tujuannya adalah pelestarian CB. Alat kontrol ini juga harus senantiasa dievaluasi, apakah berhasil atau tidak, dan apakah masih relevan atau sudah tidak sesuai dengan tuntutan zaman. Hasil evaluasi adalah rancangan alat kontrol baru yang lebih relevan. Sirkulasi ini bersifat secara terus menerus, sehingga akan tetap sesuai dengan jiwa zaman dan kondisi manusianya. Penting untuk diingat bahwa yang dikontrol tidak hanya modernisme dan manusia yang hidup didalamnya, namun juga pemerintah dan alat kontrol yang mereka ciptakan. Adapun skema perancangan dan penerapan alat kontrol pengaruh modernisme terhadap CB yakni digambarkan pada skema I.

Pada dasarnya tantangan dan harapan pelesteraian CB di wilayah Sulawesi Tenggara dapat dijadikan pihak pemerintah dan stakeholder terkait sebagai landasan untuk 


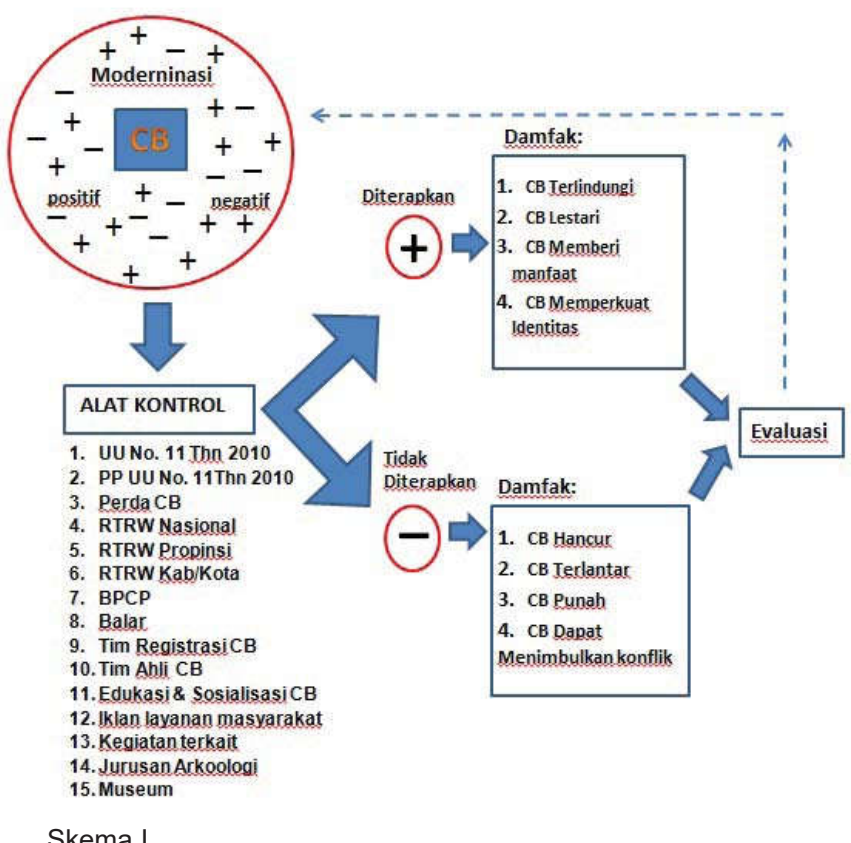

mengontrol sifat negatif modernisme terhadap CB. Alat kontrol ini tentunya akan menyesuaikan kondisi dan alam modernisme yang ada pada wilayah Provinsi Sulawesi Tenggara yang tentunya berbeda dengan wilayah lain. Alat kontrol yang telah dirancang haruslah diterapkan semaksimal mungkin, sehingga akan tercapai kelestarian CB yang ada di seluruh wilayah Sulawesi Tenggara. Sifat modernisme yang sangat dinamis mengakibatkan alat kontrolnya juga perlu dievaluasi agar tetap relevan dan sesuai dengan kondisi zaman dan kebutuhan pelestarian CB.

Belajar dari pengalaman negara lain yang telah mampu mengontrol sifat negatif modernisme terhadap CB, seperti yang dicontohkan Koji (2007), pada beberapa kasus pelestarian di Jepang, dapat disimpulkan bahwa pemerintah memegang peranan penting dalam upaya

\section{Daftar Pustaka}

Kusno, Abidin. 2009. Ruang Publik, Identitas, dan Memori Kolektif: Jakarta Pasca-Suharto. Yogyakarta: Penerbit Ombak.

Kriswandhono, A. 2013. “Tantangan dan Peluang Pengelolaan Cagar Budaya dari Perspektif Arkeologi: Kasus Kawasan Kota Lama Semarang. Hal: 39-58" artikel dalam Jurnal Konservasi Borobudur Vol. 7 No. 1, September 2013. Magelang: Balai Konservasi Borobudur pelestarian $\mathrm{CB}$, baik posisinya sebagai fasilitator, penyedia dana dan SDM, pelaksana, maupun inisiator. Peran penting pemerintah daerah selaku perpanjangan tangan pemerintah pusat, menjadi ujung tombak sekaligus penentu kondisi kelestarian CB di wilayah masing-masing, termasuk wilayah Sulawesi Tenggara. Gambaran kondisi pelestarian di wilayah Sulawesi Tenggara pada subbab sebelumnya menunjukkan sejauh mana keseriusan pemerintah dan stakeholder terkait terhadap pelestarian CB. Fakta di lapangan menyimpulkan bahwa modernisme yang tengah marak di wilayah Sulawesi Tenggara lebih bersifat negatif terhadap keberadaan CB. Sederatan kasus yang terjadi, seperti misalnya penghancuran kawasan kota lama kiranya bisa menjadi peringatan untuk kita semua. Akankah kawasan kota lama Kendari yang telah rata dengan tanah masih pantas kita panggil sebagai kota lama? Atau kita harus mencarikan nama lain, semisal kota baru? Masyarakat modern yang sejati adalah masyarakat yang paham, cinta, dan mampu melestarikan warisan budayanya. Masyarakat modern identik dengan masyarakat yang aktif dalam melestarikan warisan budayanya. Masyarakat modern merupakan cerminan masyarakat maju dalam pemikiran dan kesadaran akan pentingnya warisan budayanya sebagai penguat jati diri bangsa. Ruang publik dengan segala artefak yang dihadirkan, mengandung atau memuat memori yang dapat membantu kita untuk mengingat momen-momen yang dapat diingat bersama. Jika ruang publik dengan segala artefak di dalamnya hilang, maka kita akan kehilangan tempat untuk merajut memori kolektif (Kusno, 2009: 35). Akankah kita menjadi masyarakat modern tanpa identitas?

LPA Balai Arkeologi Makassar. 2012. Jejak-jejak Sejarah Kebudayaan Sulawesi Tenggara Daratan. Makassar: Balai Arkeologi Makassar.

Mensch, Peter Van. 2003. Museology and Management: Enemy or Friends. Current Tendencies in Theoretical Museology and Museum Management in Europe, disampaikan sebagai keynote speech, dalam Konfrensi Tabunan ke-4 Japanese Museum Management Academy(IMMA), 
Tokyo. Hal.3-19.

Mizoguchi, Koji. 2007. Identity, Modernity, and Archaeology: The Case of Japan. Dalam "A Companion to Social Archaeology. Victoria: Blackwell Publishing. Hal.396-413.

Rabani, La Ode. 2010. Kota-Kota Pantai di Sulawesi Tenggara: Perubahan dan Kelangsungannya. Yogyakarta: Penerbit Ombak.

Rahardjo, Supratikno. 2013. "Beberapa Permasalahan

Pelestarian Kawasan Cagar Budaya dan Strategi Solusinya. Hal: 3-16”. Dalam Jurnal Konservasi Cagar Budaya Borobudur Vol. 7 No. 2, Desember 2013. Magelang: Balai Konservasi Borobudur.

Thomas, Julian. 2004. Archaeology and Modernity. London: Routledge.

Supardi, Nunus. 2004. Sejarah Kelembagaan Kebudayaan di Pemerintahan dan Dinamikanya. Jakarta: Kementerian Kebudayaan dan Pariwisata.

Tanudirjo, D.A. 2003. Warisan Budaya Untuk Semua: Arah Kebijakan Pengelola Warisan Budaya Indoensia Di Masa Mendatang. Makalah disampaikan pada Kongres Kebudayaan V, Bukittinggi, 19-23 Oktober 2003.

2006. Pengelolaan Sumberdaya Budaya

Di Perkotaan. Makalah disampaikan pada Seminar Pengelollan Warisan Budata di Hotel Suwarnadwipa Pelembang, 30-31 Mei.

Pelras, Christian. 2005. "Budaya Bugis: Sebuah Tradisi Modernitas". Dalam Tapak-Tapak Waktu. Makassar: Penerbit Ininnawa.

\section{Perundangan}

Netherland East Indie. 1931. Monumenten Ordonnantie No. 19 Tahun 1931 Tentang Cagar Budaya
Pemerintah Kota Kendari. 2013. Peraturan Daerah No. 21 Tahun 2013 Tentang Cagar Budaya Kota Kendari

Republik Indonesia. 1992. Undang-Undang No. 5 Tahun 1992 Tentang Benda Cagar Budaya

Republik Indonesia. 2010. Undang-Undang No. 11 Tahun 2010 Tentang Cagar Budaya

Republik Indonesia. 2008. Peraturan Pemerintah No. 26 Tahun 2008 Tentang Pedoman Rencana Tata Ruang Wilayah Nasional.

Republik Indonesia. 2009. Permen PU No. 15 Tahun 2009 Tentang Pedoman Penyusunan RTRW Provinsi

\section{Website}

Anonim. 2010. Tolak Penghancuran Eks Bioskop Garuda-Surya. http://regional.kompas. $\mathrm{com} / \mathrm{read} / 2010 / 02 / 26 / 01390218 /$ Tolak. Penghancuran.Eks.Bioskop.Garuda-Surya. Diunduh pada pukul 12:00 WITA, 5 Mei 2015.

Atmojo, Junus Satrio. 2012. Perlindungan Warisan Budaya Daerah Menurut Undang-undang Cagar Budaya. https://iaaipusat.wordpress. com $/ 2012 / 03 / 17 /$ perlindungan-warisanbudaya-daerah-menurut-undang-undang-cagarbudaya. Diunduh pada pukul 09:00 WITA, 5 Mei 2015.

Ibrahim, Anis. 2015. Rakyat Bisa Somasi Pemkab. http:// pedomannusantara.com/berita-perbup-cagarbudaya-tak-jelas.html. Diunduh pada pukul 09:00 WITA, 5 Mei 2015. 